\title{
Copper Hydroxide Improved Root Quality of Palimara Alstonia in Plastic Containers
}

\author{
Yu-Sen Chang ${ }^{1}$ and Chen-Yu Lin ${ }^{2}$
}

\begin{abstract}
AdDitional INDEX WORDs. Alstonia scholaris, container production, root circling, root length, root: shoot ratio, shoot growth

Summary. The effect of copper hydroxide $\left[\mathrm{Cu}(\mathrm{OH})_{2}\right]$ applied to interior container surfaces on shoot and root responses was evaluated on palimara alstonia ( $\mathrm{Al}$ stonia scholaris). The seedlings grown in $\mathrm{Cu}(\mathrm{OH})_{2}$-treated containers had greater plant height than those in untreated containers, and had no observable copper toxicity symptoms. $\mathrm{Cu}(\mathrm{OH})_{2}$-treated containers effectively reduced root circling on the surface of rootballs compared with untreated containers. The $\mathrm{Cu}(\mathrm{OH})_{2}$ treatment significantly increased the dry weight of fine roots (those with a diameter 0-2 $\mathrm{mm}$ ) and small roots $(>2-5 \mathrm{~mm}$ ) but did not influence the dry weight of medium roots $(>5-10 \mathrm{~mm})$, large roots $(>10 \mathrm{~mm})$, or total roots. The $\mathrm{Cu}(\mathrm{OH})_{2}$ treatment also significantly increased total root length and surface, which was due principally to the increasing length and surface of the fine roots. The results indicated that the $\mathrm{Cu}(\mathrm{OH})_{2}$ treatment, which can improve the root quality of palimara alstonia seedlings and thereby increase the root-length-to-leaf-area ratio and the root-surface-to-leaf-area ratio, has the potential to produce high-quality plants.
\end{abstract}

$\mathrm{C}$ ontainer production of nursery crops offers numerous advantages over field production (Whitcomb, 1984). However, root circling or malformation is an inherent problem with container-grown plants, especially vigorous plant species, like palimara alstonia (Ruter, 1994), that are held too long in a given container (Whitcomb and Williams, 1985). Chemical reduction or elimination of root circling via application of copper hydroxide (cupric hydroxide) to interior surfaces of containers before production has proven to be effective with many species (Arnold and Struve, 1993; Beeson and Newton, 1992; Brass et al., 1996, 1997; Struve, 1994; Svenson et al., 1995).

Although the effects of copper $(\mathrm{Cu})$-treated containers on root growth during container production have been well documented, few studies have investigated the length of roots of various diameters. It is generally accepted that root absorption of water and minerals is more directly related

Department of Horticulture, National Taiwan University, No. 1, Section 4, Roosevelt Road, Taipei, Taiwan, 10617 R.O.C.

Acknowledgment. The authors would like to thank the Council of Agriculture, Executive Yuan, R.O.C., for financially supporting this research under Contract No. 9lAS-1.1.2-FD-Zl(2).

${ }^{1}$ Professor; e-mail: yschang@ntu.edu.tw

${ }^{2}$ Master. to root length than to root weight (Svenson and Johnston, 1995). The objective of this study was to evaluate the effects of $\mathrm{Cu}(\mathrm{OH})_{2}$-treated containers on root and shoot responses, especially root length and root surface of various diameters, during production of palimara alstonia plants.

\section{Materials and methods}

On 21 Oct. 1997, 1-year-old seedlings of palimara alstonia were planted in black plastic, 11.0-L containers $(26.0-\mathrm{cm}$ diameter, 23.5 $\mathrm{cm}$ tall) filled with a 3 pine bark: 1 peatmoss: 1 sand mixture (by volume) supplemented with $25 \mathrm{~g}$ of $14 \mathrm{~N}-6.2 \mathrm{P}-11.6 \mathrm{~K}$ Osmocote (The Scotts Co., Marysville, Ohio) per pot. Before filling the pots with medium, the interior surfaces of half of the pots were sprayed with a liquid latex-
$\mathrm{Cu}(\mathrm{OH})_{2}$ compound $\left[\mathrm{Cu}(\mathrm{OH})_{2} 100\right.$ g. $\mathrm{L}^{-1}, \sim 4.6 \%$ metallic $\mathrm{Cu}$ equivalent], formulated as Spin Out (Griffin Corp., Valdosta, Ga.), and the other half were left untreated.

The plants were placed in an open area of the Experimental Farm, National Taiwan University, Taipei. During the experimental period, the plants were watered at 1 - to 2 -d intervals and were fertilized at weekly intervals with $2000 \mathrm{~mL}$ of $20 \mathrm{~N}-8.7 \mathrm{P}-16.5 \mathrm{~K}$ liquid fertilizer (Peters Professional watersoluble fertilizer; The Scotts Co.) per pot at $\mathrm{N}$ concentration of $200 \mathrm{mg} \cdot \mathrm{L}^{-1}$. Each treatment was arranged in a completely randomized design with six single-plant replications.

Plant height, stem diameter 15 $\mathrm{cm}$ above the medium surface, and number of total leaves were recorded at monthly intervals. On 2 July 1998, the seedlings were harvested to determine the total leaf area and shoot (stems and leaves) dry weight $\left(3 \mathrm{~d}\right.$ drying at $\left.70^{\circ} \mathrm{C}\right)$. Root coverage on the exterior of the rootball was rated using the following scale: $1=<20 \%$ of the rootball covered with white root tips, no root circling; $3=\sim 50 \%$ of the rootball covered with white root tips, moderate root circling; and $5=>80 \%$ of the rootball covered with white root tips, extensive root circling (Ruter, 1994; Svenson et al., 1995). After rating the root coverage, roots were washed free of medium and were separated into four diameter classes: fine $(0-2 \mathrm{~mm})$, small $(>2-5$ $\mathrm{mm})$, medium ( $>5-10 \mathrm{~mm})$, and large $(>10 \mathrm{~mm})$ (Gilman and Beeson, 1995). The root length of each diameter class was estimated using CI-203RL Root Measurement Attachment (CID, Inc., Vancouver, Wash.) before the roots were dried.

Root surface was estimated using the following equation (Gilman and Beeson, 1995):

\begin{tabular}{lllc}
\hline $\begin{array}{l}\text { Units } \\
\begin{array}{l}\text { To convert U.S. to SI, } \\
\text { multiply by }\end{array}\end{array}$ & U.S. unit & SI unit & $\begin{array}{l}\text { To convert SI to U.S., } \\
\text { multiply by }\end{array}$ \\
\hline 29.5735 & $\mathrm{fl} \mathrm{oz}$ & $\mathrm{mL}$ & 0.0338 \\
0.3048 & $\mathrm{ft}$ & $\mathrm{m}$ & 3.2808 \\
0.0929 & $\mathrm{ft}^{2}$ & $\mathrm{~m}^{2}$ & 10.7639 \\
3.7854 & gal & $\mathrm{L}$ & 0.2642 \\
2.54 & inch(es) & $\mathrm{cm}$ & 0.3937 \\
25.4 & inch(es) & $\mathrm{mm}$ & 0.0394 \\
6.4516 & inch & $\mathrm{cm}^{2}$ & 0.1550 \\
28.3495 & $\mathrm{Oz}$ & $\mathrm{g}$ & 0.0353 \\
0.001 & $\mathrm{ppm}$ & $\mathrm{g} \cdot \mathrm{L}^{-1}$ & 1000 \\
1 & $\mathrm{ppm}$ & $\mathrm{mg} \cdot \mathrm{L}^{-1}$ & 1 \\
$\left({ }^{\circ} \mathrm{F}-32\right) \div 1.8$ & ${ }^{\circ} \mathrm{F}$ & ${ }^{\circ} \mathrm{C}$ & $\left(1.8 \times{ }^{\circ} \mathrm{C}\right)+32$
\end{tabular}


Total root surface

$=(1.0 \mathrm{~mm} \times \pi \times$ length of fine roots $)$

$+(3.5 \mathrm{~mm} \times \pi \times$ length of small roots $)$

$+(7.5 \mathrm{~mm} \times \pi \times$ length of medium roots $)$

$+(12.5 \mathrm{~mm} \times \pi \times$ length of large roots $)$

All data were analyzed using analysis of variance with mean separations by least squares means (SAS Institute, 1989).

\section{Results and discussion}

Copper hydroxide-treated containers decreased the amount of circled, kinked, and matted roots formed at the container wall-medium interface in palimara alstonia. As indicated by the root coverage, $\mathrm{Cu}(\mathrm{OH})_{2}$-treated containers had significantly improved less root malformation and root circling on the exterior of the rootball (Table 1). However, $\mathrm{Cu}(\mathrm{OH})_{2}$ treatment reduced, but did not completely eliminate, root growth at the bottom of the containers. Beeson and Newton (1992), Svenson et al. (1995), and Schuch and Pittenger (1996) reported similar results for species like lemonscented gum (Eucalyptus citriodora), bald cypress (Taxodium distichum), laurel oak (Quercuslaurifolia), peperomia (Peperomia serpens), and emerald tree (Radermachera sinica). As palimara alstonia is a fairly fast-growing species (Riffle, 1998), this may be one of the reasons why root growth on the surface of the rootball was not eliminated completely for palimara alstonia.

Throughout the study, neither $\mathrm{Cu}$ toxicity in the leaves nor other shoot abnormalities were observed. Palimara alstonia seedlings grown in $\mathrm{Cu}(\mathrm{OH})_{2}^{-}$ treated containers were significantly taller than those grown in untreated containers (Table 2). This result is consistent with the responses of green ash (Fraxinus pennsylvania) (Arnold and Struve, 1989), mahogany (Swietenia mahagoni) (Beeson and Newton, 1992), and west indian holly (Leea coccinea) (Svenson et al., 1995).

Previous studies have documented that $\mathrm{Cu}$-treated containers generally decrease root elongation (Svenson and Johnston, 1995); and increase root branching (Arnold and Struve, 1989), the number of actively growing root tips and new roots (Arnold, 1996; Arnold and Young, 1991), and the uniformity of root distribution with the rootball (Arnold and Struve, 1993). Our data showed that $\mathrm{Cu}(\mathrm{OH})_{2}$ treatment did not effectively increase the

Table 1. Effects of copper hydroxide $\left[\mathrm{Cu}(\mathrm{OH})_{2}\right]$-treated $(+)$ and untreated $(-)$ containers on root responses of palimara alstonia. ${ }^{z}$

\begin{tabular}{|c|c|c|c|c|c|c|}
\hline \multirow[b]{2}{*}{$\begin{array}{l}\mathrm{Cu}(\mathrm{OH})_{2} \\
\text { treatment }\end{array}$} & \multicolumn{4}{|c|}{ Root diam class $(\mathrm{mm})^{\mathrm{y}}$} & \multirow[b]{2}{*}{ Total } & \multirow{2}{*}{$\begin{array}{c}\text { Root } \\
\text { coverage } \\
(1-5 \text { scale })^{\mathrm{y}}\end{array}$} \\
\hline & $\begin{array}{c}\text { Fine } \\
(0-2)\end{array}$ & $\begin{array}{c}\text { Small } \\
(>2-5)\end{array}$ & $\begin{array}{l}\text { Medium } \\
(>5-10)\end{array}$ & $\begin{array}{l}\text { Large } \\
(>10)\end{array}$ & & \\
\hline
\end{tabular}

\begin{tabular}{|c|c|c|c|c|c|c|}
\hline \multicolumn{7}{|c|}{ Root dry wt $(g)^{\mathrm{x}}$} \\
\hline- & 9.1 & 3.7 & 5.0 & 33.8 & 51.7 & 4.7 \\
\hline \multirow[t]{2}{*}{+} & 14.7 & 8.4 & 7.6 & 35.3 & 66.1 & 2.7 \\
\hline & * & * & NS & NS & NS & $* *$ \\
\hline \multicolumn{7}{|c|}{ Root length $(m)^{\mathrm{x}}$} \\
\hline- & 657.32 & 4.34 & 0.92 & 0.28 & 662.86 & \\
\hline \multirow[t]{2}{*}{+} & 1952.58 & 5.31 & 1.21 & 0.26 & 1959.36 & \\
\hline & *** & NS & NS & NS & $* * *$ & \\
\hline \multicolumn{7}{|c|}{ Root surface $\left(m^{2}\right)^{\mathrm{x}, \mathrm{w}}$} \\
\hline- & 2.065 & 0.048 & 0.022 & 0.011 & 2.146 & \\
\hline+ & 6.134 & 0.058 & 0.029 & 0.010 & 6.231 & \\
\hline & $* * *$ & NS & NS & NS & $* * *$ & \\
\hline
\end{tabular}

${ }^{2}$ Value is the mean of six observations.

'Root coverage: $1=<20 \%$ of rootball covered with white root tips, no root circling; $3=\sim 50 \%$ of rootball covered with white root tips, moderate root circling; $5=>80 \%$ of rootball was covered with white root tips, extensive root circling.

${ }^{x} 1 \mathrm{~mm}=0.0394$ inch; $1 \mathrm{~g}=0.0353 \mathrm{oz} ; 1 \mathrm{~m}=3.2808 \mathrm{ft} ; 1 \mathrm{~m}^{2}=10.7639 \mathrm{ft}^{2}$.

wTotal root surface $=(1.0 \mathrm{~mm} \times \pi \times$ length of fine roots $)+(3.5 \mathrm{~mm} \times \pi \times$ length of small roots $)+(7.5 \mathrm{~mm} \times \pi$ $\times$ length of medium roots $)+(12.5 \mathrm{~mm} \times \pi \times$ length of large roots $)$.

Ns, ${ }^{*},{ }^{* *},{ }^{* \star *}$ Nonsignificant or significant at $P \leq 0.05,0.01$, or 0.001 , respectively.

Table 2. Effects of copper hydroxide $\left[\mathrm{Cu}(\mathrm{OH})_{2}\right]$-treated $(+)$ and untreated (-) containers on shoot responses of palimara alstonia. ${ }^{\mathrm{z}}$

\begin{tabular}{lcccccc}
\hline $\begin{array}{l}\mathrm{Cu}(\mathrm{OH})_{2} \\
\text { treatment }\end{array}$ & $\begin{array}{c}\text { Plant ht } \\
(\mathbf{c m})^{\mathrm{y}}\end{array}$ & $\begin{array}{c}\text { Stem } \\
\text { diam } \\
(\mathbf{m m})^{\mathrm{y}}\end{array}$ & $\begin{array}{c}\text { Leaves } \\
(\mathbf{n o} .)\end{array}$ & $\begin{array}{c}\text { Total leaf } \\
\text { leaf area } \\
\left(\mathbf{c m}^{2}\right)^{\mathrm{y}}\end{array}$ & $\begin{array}{c}\text { Total leaf } \\
\text { leaf dry wt } \\
(\mathrm{g})^{\mathrm{y}}\end{array}$ & $\begin{array}{c}\text { Total stem } \\
\text { dry wt } \\
(\mathrm{g})\end{array}$ \\
\hline- & 159.9 & 24.2 & 70.5 & 4428.3 & 30.8 & 91.4 \\
+ & 173.0 & 25.2 & 73.7 & 4844.9 & 34.4 & 95.1 \\
& $*$ & NS & NS & NS & NS & NS \\
\hline
\end{tabular}

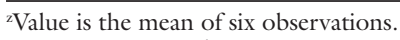

${ }^{y} 1 \mathrm{~cm}=0.3937$ inch; $1 \mathrm{~mm}=0.0394$ inch; $1 \mathrm{~cm}^{2}=0.1550$ inch $^{2} ; 1 \mathrm{~g}=0.0353 \mathrm{oz}$.

Ns, * Nonsignificant or significant at $P \leq 0.05$, respectively.

dry weight of medium roots $(>5-10$ $\mathrm{mm}$ in diameter), large roots $(>10$ $\mathrm{mm}$ in diameter), and total roots, but it did significantly increase that of fine roots $(0-2 \mathrm{~mm}$ in diameter $)$ and small roots $(>2-5 \mathrm{~mm}$ in diameter). In addition, the $\mathrm{Cu}(\mathrm{OH})_{2}$ treatment did not significantly increase the length or surface of small, medium, and large roots but did significantly increase the total root length or surface, which was principally caused by an increase in the length or surface of fine roots (Table 1). These results indicate that $\mathrm{Cu}(\mathrm{OH})_{2}$ treatment can improve the root system of palimara alstonia seedlings and can contribute to great water and mineral nutrient uptake (Arnold, 1996; Arnold and Struve, 1993). Consequently, it can increase plant height or shoot growth.

The root-to-shoot ratio is usually given as the ratio of the dry weight of the root to the dry weight of the shoot. Many arborists believe that a reduction in the root-to-shoot ratio of a plant is undesirable (Harris, 1992). However, root-to-shoot ratios are also reduced in many species grown in $\mathrm{Cu}$-treated containers, which is due to increased shoot growth and/or reduced root growth (Beeson and Newton, 1992; Svenson et al., 1995). Harris (1992) pointed out that relative root and shoot weights are not a valid measure of the adequacy of the roots to supply water and nutrients and that a more useful comparison is the root length or surface to the transpiring leaf surface of a plant. In this study, $\mathrm{Cu}(\mathrm{OH})_{2}$-treated containers did not affect the root-to-shoot ratio (dry w/w) and root-to-leaf ratio (by dry weight) but did significantly increase the root-length-to-leaf-area ratio and root-surface-to-leaf-area ratio (Table 3 ). 
Table 3. Effects of copper hydroxide $\left[\mathrm{Cu}(\mathrm{OH})_{2}\right]$-treated $(+)$ and untreated (-) containers on root responses to shoot relationships of palimara alstonia. ${ }^{z}$

\begin{tabular}{lcccc}
\hline $\begin{array}{l}\mathrm{Cu}(\mathrm{OH})_{2} \\
\text { treatment }\end{array}$ & $\begin{array}{c}\text { Root dry wt: } \\
\text { shoot dry wt } \\
\left(\mathrm{g} \cdot \mathrm{g}^{-1}\right)^{\mathrm{y}}\end{array}$ & $\begin{array}{c}\text { Root dry wt: } \\
\text { leaf dry wt } \\
\left(\mathrm{g} \cdot \mathrm{g}^{-1}\right)\end{array}$ & $\begin{array}{c}\text { Root length: } \\
\text { leaf area } \\
\left(\mathrm{cm}^{-1} \mathrm{~cm}^{-2}\right)^{\mathrm{y}}\end{array}$ & $\begin{array}{c}\text { Root surface: } \\
\text { leaf area } \\
\left(\mathrm{cm}^{2} \cdot \mathrm{cm}^{-2}\right)\end{array}$ \\
\hline- & 0.43 & 1.68 & 14.9 & 4.8 \\
+ & 0.52 & 1.92 & 40.4 & 12.8 \\
& $\mathrm{NS}$ & $\mathrm{NS}$ & $* * *$ & $* * *$ \\
\hline
\end{tabular}

${ }^{2}$ Value is the mean of six observations.

${ }^{\mathrm{y}} \mathrm{l} \mathrm{g}=0.0353 \mathrm{oz} ; 1 \mathrm{~cm}=0.3937$ inch; $1 \mathrm{~cm}^{2}=0.1550$ inch $^{2}$.

ss, ${ }^{*}, * * *$ Nonsignificant or significant at $P \leq 0.05$ or 0.001 , respectively.

The results of this study indicate that plants grown in $\mathrm{Cu}(\mathrm{OH})_{2}$-treated containers have greater length or surface of total roots, especially that of fine roots, but have less circled, kinked, and matted roots on the surface of the rootball. Thus, $\mathrm{Cu}(\mathrm{OH})_{2}$ treatment can improve the root quality of palimara alstonia seedlings and has the potential to produce high-quality plants.

\section{Literature cited}

Arnold, M.A. 1996. Mechanical correction and chemical avoidance of circling roots differentially affect post-transplant root generation and field establishment of container-grown shumard oak. J. Amer. Soc. Hort. Sci. 121:258-263.

Arnold, M.A. and D.K. Struve. 1989. Cupric carbonate controls green ash root morphology and root growth. HortScience 24:262-264.

Arnold, M.A. and D.K. Struve. 1993. Root distribution and mineral uptake of coarse-rooted trees grown in cupric hydroxide-treated containers. HortScience 28:988-992.
Arnold, M.A. and E. Young. 1991. $\mathrm{CuCO}_{3}^{-}$ painted containers and root pruning affect apple and green ash root growth and cytokinin levels. HortScience 26:242-244.

Beeson, R.C., Jr. and R. Newton. 1992. Shoot and root responses of eighteen southeastern woody landscape species grown in cupric hydroxide-treated containers. J. Environ. Hort. 10:214-217.

Brass, T.J., G.J. Keever, D.J. Eakes, and C.H. Gilliam. 1996. Styrene-lined and copper-coated containers affect production and landscape establishment of red maple. HortScience 31:353-356.

Brass, T.J., G.J. Keever, C.H. Gilliam, D.J. Eakes, and C.P. Hesselein. 1997. Production of six woody landscape plants in copper-coated and styrene-lined containers. J. Environ. Hort. 15:73-76.

Gilman, E.F. and R.J. Beeson. 1995. Copper hydroxide affects root distribution of Ilex cassine in plastic containers. HortTechnology 5:48-49.

Harris, R.W. 1992. Arboriculture, integrated management of landscape trees, shrubs, and vines. 2nd ed. Prentice-Hall, Englewood Cliffs, N.J.
Riffle, R.L. 1998. The tropical look: An encyclopedia of dramatic landscape plants. Timber Press, Portland, Ore.

Ruter, J.M. 1994. Growth responses of four vigorous-rooted tree species in cupric hydroxide-treated containers. HortScience 29:1089.(Abstr.)

SAS Institute Inc. 1989. SAS/STAT user's guide. Version 6. SAS Inst., Cary, N.C.

Schuch, U.K. and D.R. Pittenger. 1996. Root and shoot growth of Eucalyptus in response to container configuration and copper carbonate. HortScience 31:165 (Abstr.).

Struve, D.K. 1994. Street tree establishment, p. 78-88. In: G.W. Watson and D. Neely (eds.). The landscape below ground. Intl. Soc. Arboricult., Savoy, Ill.

Svenson, S.E. and D.L. Johnston. 1995. Rooting cuttings in cupric hydroxidetreated pots affects root length and number of flowers after transplanting. HortScience 30:247-248.

Svenson, S.E., D.L. Johnston, and B.L. Coy. 1995. Shoot and root responses of eight subtropical species grown in cupric hydroxide-treated containers. HortScience 30:249-251.

Whitcomb, C.E. 1984. Plant production in containers. Lacebark, Chicago.

Whitcomb, C.E. and J.D. Williams. 1985. Stair-step container for improved root growth. HortScience 20:66-67. 